Studia Anglica Posnaniensia 47, 2-3, 2012

doi: 10.2478/v10121-012-0009-5

\title{
ICONICIZING KINGSHIP IN ELIZABETHAN ENGLAND: STRATEGIC ACTING BY QUEEN ELIZABETH I
}

\author{
URSZULA KIZELBACH
}

Adam Mickiewicz University, Poznań

\begin{abstract}
Renaissance England is often discussed in the context of theatre and theatrical acting. The fact is that Renaissance monarchs, too, viewed kingship in terms of theatrical display and public performance. Such is the nature of royalty presented by King James I in Basilicon Doron. Queen Elizabeth I was playing all her life. Faced with the problem of her femininity in the world of men, as well as her ambivalent hereditary rights as a member of the Tudor dynasty, she focused on legitimizing her reign through playing different roles - she played the fearful king, the loving queen, she even played Virgin Mary. But Elizabeth emerges as the most stunning actress when she plays herself. On her summer visit to Wanstead in 1578 she took an active part in the pageant "The lady of May", playing herself, "Good Queen Bess", which Sir Philip Sidney depicted in his pastoral romance The lady of May. In this way, Elizabeth became her own icon. This paper provides instances of the Queen's political role play in a historical and socio-cultural context of the time.
\end{abstract}

Renaissance monarchs perceived kingship as theatre and play, pointing out the public character of their office. King James I, Elizabeth's successor, described the nature of royalty in his Basilicon Doron, a royal treatise on kingship dedicated to his son. In an address to the Reader we learn that

$[\mathrm{k}]$ ings being publike persons, by reasons of their office and authority, are as it were set ... upon a publike stage, in the sight of all the people; where all the beholders eyes are attentively bent to looke and pry in the least circumstance of their secretest drifts: Which should make Kings the more carefull not to harbour the secretest thought in their minde, but such as in the owne time they shall not be ashamed openly to avouch... (Basilicon Doron, 202). 
King James alludes to the metaphorical stage or scaffold on which kings are put and where they are "in the sight of all the people". As public persons they are put on display, and they are judged by the critical eyes of their citizens. Supporting the favourable royal image through public entries and processions since medieval times has been a vital part of English kings' reign. Beginning with Henry VII, monarchs displayed themselves to their people, and manifested the grandeur of majesty in, for example, attending royal progresses. In the Renaissance, public self-exhibition by kings evolved into a modern way of ruling, the "Machiavellian" policy of theatrical display, where kings can manipulate their audiences' reactions, where they create their own legend. Politics and theatre were closely connected in the Renaissance England, where, to quote David Scott Kastan (1991: 246), "the theatricalized world of Elizabethan politics" and "the politicized world of the Elizabethan theatre" intermingled. Power is most effectively exercised by a king when it is "shown" in public through theatrical staging, which was also the case in the Elizabethan politics, which involved spectacular performance, acting and role playing.

Elizabeth I began her reign in 1558, and on 15 January 1559 she was officially crowned as the English queen. Her life, as the daughter of king Henry VIII, heavily influenced her kingship. From childhood Elizabeth was struggling with uncertainty and fear about the future - Anne Boleyn, her mother and the second wife of Henry VIII, was decapitated for treason and adultery on 19 May 1536, when Elizabeth was approaching three years old. Her right to the throne had, seemingly, been regulated by the Act of Succession issued at a spring session of Parliament in 1534, which vested all hereditary titles in the offspring of Henry and Anne Boleyn and at the same time dissolved his first marriage with Catherine of Aragon (Bindoff 1950: 102). However, after her mother's death Elizabeth was declared a bastard with no right to the throne: now she shared the same fate with princess Mary, the daughter of Henry's first wife Catherine. It is with the appearance of Henry's third wife, Jane Seymour, that Elizabeth was accepted anew as a pretender to the throne after Mary Tudor. At the age of 21 Elizabeth was accused of treason and was suspected by her sister Mary of supporting the Protestant plot of Thomas Wyatt, popularly called the Wyatt's rebellion (1554). She was put under house arrest in Whitehall and Woodstock for a couple of months. She was also placed in the Tower to await death at the block. Fortunately, she was released from prison as there was not enough convincing evidence against her. It is only at the age of 25 that Elizabeth becomes a queen, and her uneasy rule is marked by rebellions and plots against her life $^{1}$, by her shunning the advances

For example, the Northern rebellion (1569), the Ridolfi plot (1570), the Babington plot (1586), the Earl of Essex's revolt (1599). 
of the greatest monarchs of Europe, and by her difficult decision to sign the death warrant of her cousin Mary Stuart.

Did Queen Elizabeth I need acting during her reign? She definitely did, more than any of her (male) predecessors. The patriarchal Renaissance England was not in favour of a female monarch, and Elizabeth took up the throne feeling the misogynistic atmosphere at court which accompanied her succession. The year 1558 is the date of the publication of John Knox's pamphlet against female rule First blast of the trumpet against the monstrous regiment of women. Knox, a great Scottish reformer and a fierce enemy of Catholicism directed his criticism mainly at Mary Tudor, and he probably did not expect that Elizabeth I would become his Queen just a couple of months after this publication. In his book he gives three sorts of reasons why women should not have authority over men: first, there are reasons stemming from the law of nature, second, reasons grounded in civil law, third, reasons concerning the sacred law of God. He postulates that it is against nature that a woman should have power over man and that God did not establish female monarchs just as he did not establish female priests. He believes that women by nature are weaker and thus unable to rule, and only wicked and proud women seek domination while foolish men allow it (Levin 1994: 10). Knox definitely sees the troubles of the nation in the "usurped authority" of women:

\footnotetext{
We se our countrie set further for a pray of foreine nations, we heare the blood of our brethren, the members of Christ Iesus most cruellie to be shed, and the monstrous empire of a cruell women ... we knowe to be the onlie occasion of all the miseries (Arber 2006: 9).
}

Elizabeth was slightly appeased by John Aylmer's treatise published in the same year, Harborrowe for faithfull and trewe subjects. Aylmer had fled from England under Catholic Mary Tudor, but he accepted Elizabeth as Queen being, through her birth, sent by God to the English throne. However, he supported the idea of a limited authority of a female monarch and imagined her to be modest, wearing simple dresses, heeding male advice and, naturally, married (Levin 1994: 12). Elizabeth was fully aware of the fact that everybody expected her to marry, and yet, at the same time, to remain a 'king'.

Faced with the problem of her "unwanted" femininity as well as her ambivalent hereditary rights as a member of the Tudor dynasty, Queen Elizabeth I was focused on legitimizing her reign through playing the roles of both queen and king to meet the expectations of her people. Levin (1994: 131) states that she "fashion[ed] the way people perceived her and ... used male analogies with which to compare herself, and presented herself in a dramatic fashion". Entering the male world of crude Realpolitik, she had to hide her real identity and relied on a "Machiavellian self-fashioning", which helped her emerge in public as a 
strong "self-promoting Prince" (Montini 1999: 211). In fact, Elizabeth was a queen playing a king in official situations, and the first such display was her theatrical prayer during her coronation procession. As we read in Holinshed's Chronicles, she stopped at the Tower, where she had been imprisoned by Mary Tudor, and, thanking God for her deliverance from death, she evoked the biblical image of the prophet Daniel saved from the lions:

I acknowledge that thou hast dealt as woonderfullie and as mercifullie with me as
Thou diddest with thy true and faithfull servant, Daniell thy prophet; whome thou
deliveredst out of the den from the crueltie of the greedie and raging lions: even
so was I overwhelmed and only by thee delivered (Ellis 1807-8: 176).

Elizabeth in her speech of deliverance compares herself to Daniel, famed for saving Israel from the Canaanite king - her gender would rather suggest a different choice, that of Deborah, the prophetess in the Bible (Levin 1994: 131132). It cannot be denied that in her manner as well as in her speeches to Parliament she was pursuing the image of a masculine, brave woman, often comparing herself to her father: "and though I be a woman, yet I have as good a courage answerable to my place as ever my father had" (Marcus et al. 2000: 97). The expectations of her gender, those of weakness and feebleness of character, stood no comparison with her real image: she was a mixture of Anne Boleyn's playfulness and Henry VIII's imperious nature, and, as Black (1959: 2) states "[c]lose beneath her winsome, debonair exterior lay the terribilità of the Tudor 'lion"'.

It is important to remember that the English Parliament was very anxious about the matter of Elizabeth's succession and marriage. Mueller (2000: 1063) points out that earliest Elizabethan parliaments working in 1558-59, 1563 and 1566 were "obsessed" with the problem of her status as a single woman. Each next Parliament declared a continuing crisis of authority and urged the young queen to marry (this sounds reasonable, as in case of the queen's sudden death England would remain without a ruler). Naming a successor, which she refused to do, was extremely important in the moments of crisis, for example, when the Queen came down with smallpox in 1572. Elizabeth had to publicly answer the Parliament's numerous petitions urging her to marry. Some of her arguments she presents in her answer to the Commons in 1559, the year of her coronation, at the age of 25 :

... it is long since I had any joy in the honour of a husband; and this is that I thought, then that I was a private person. But when the public charge of governing the kingdom came upon me, it seemed unto me an inconsiderate folly to draw upon myself the cares which might proceed of marriage. To conclude, I am already bound unto a husband, which is the kingdom of England, and that may suffice you (Marcus et al. 2000: 59). 
In this speech Elizabeth makes a distinction between her "private self", which would not mind a husband, and her "public self", which has to focus on the matters of the state. ${ }^{2}$ Despite her adamant objection to marry and have children, Elizabeth by no means ceases to be a woman; she assures her court that all Englishmen are her offspring, and that she will take good care of them: "And reproach me so no more that I have no children: for every one of you, and as many as are English, are my children and kinsfolks" (Marcus et al. 2000: 59). Rose (2002: 28) believes that Elizabeth in her public rhetoric played with her gender and manipulated different metaphors and images to gain political advantage. Here she creates the image of an all-loving mother, a "nurturer" (Rose 2002: 33), the queen who devotes her personal happiness to her subjects. As Rose (2002: 28) claims, in her speeches she manipulates her femininity to create a metaphor of herself as the Virgin Mary, mainly through numerous allusions to her own virginity as an unmarried woman. In her speech to Parliament of 10 February 1559 she declares she wants to stay a virgin forever: "And in the end this shall be for me sufficient: that a marble stone shall declare that a queen ... lived and died a virgin" (Marcus et al. 2000: 58). ${ }^{3}$ In one of her last speeches of 1601 she reminds her folk about her sacrifice: "I have diminished my own revenue that I might add to your security, and been content to be a taper of true virgin wax, to waste myself and spend my life that I might give light and comfort to those that live under me" (Marcus et al. 2000: 347). Thus, among the roles the Queen plays are the typically female ones of a virgin and a mother.

Elizabeth displayed her acting skills earlier, in the pre-coronation entry into the city of London on 14 January 1559, a day before her coronation. The procession followed a route from the Tower to Westminster, and stopped at some points (Cheapside, St. Paul's Cathedral) to watch pageants, tableaux and triumphal arches prepared by the citizens. This event started with the welcome speech given by the Recorder of London, and was followed by the presentation of gifts to a monarch by the city (Lees-Jeffries 2007: 65). As we know from Richard Mulcaster's pamphlet The passage of our most dread sovereign lady (1558), at Cheapside the Queen was presented with a purse of gold, the amount of a hundred marks, by the Recorder, and this is what she said in return:

2 "I am and not; I freeze and yet am burn'd; / Since from myself, my other self I turn'd" is Elizabeth's poem On monsieur's departure, which commemorates Francis Duke of Alençon's leaving in 1582. Alençon was one of Elizabeth's suitors, his offer of marriage represented a political alliance expected by the Parliament, which the Queen rejected. Cerasano and Wynne-Davies (1992: 8) claim this poem to be an expression of Elizabeth's double self and her "shifting identity" as an ordinary woman and Queen.

3 Elizabeth's last wish presented in a 1559 speech is that when she will lie buried, she would like an inscription on her tomb saying: "Here lies interred Elizabeth, / A virgin pure until her death" (Marcus et al. 2000: 60). 
I thank my lord mayor, his brethren, and you all. And wheras your request is that I should continue your good ladie and queen, be ye ensured, that I will be as good unto you, as ever quene was to her people. No wille in me can lacke, neither doe I trust shall ther lacke any power. And perswade your selves, that for the safetie and quietness of you all, I will not spare, if need be to spend my blood, God thanke you all (Mulcaster 1559: 46).

This royal address to the people Bergeron (1971: 15) labels as a "histrionic response ... [of] an unscheduled actor", a speech delivered extempore to the delight of the audience. Surely, this is another example of Elizabeth's actorship and histrionics - her first performance was the prayer to God for her delivery from death, which she spoke at the Tower. Next, Elizabeth saw a cave located between two hills: she noticed an old man wearing artificial wings and holding a scythe, he was accompanied by a girl dressed in white silk. It was "Time" and his daughter "Truth", who carried another gift, the gift of "Verbum Veritatis" or "the word of Truth", that is, the English Bible. The Speaker was given the book and then he handed it over to Sir John Parrat, who handed it to the Queen. Mulcaster reports that she accepted the gift and "as soone as she has receivd the booke, [she] kyssed it, and with both her handes held up the same, and so laid it upon her breast, with great thankes to the citie therfore" (as quoted in: Bergeron 1971: 20). To follow Bergeron (1971: 20-21), Elizabeth rose up to all expectations; her theatrical behaviour (kissing the Bible and laying it on her breast, thanking citizens) was "strik[ing] a dramatic pose", playing the kind of king people were waiting for. Moreover, Elizabeth conveyed an important political message, namely, that her kingship will cherish above all the word of God, Truth and (Protestant) religion.

Royal entries were "urban manifestations of the desire to celebrate sovereign power" (Leahy 2005: 1). They were always pieces of cunningly weaved propaganda by means of which Elizabethan monarchy "fashion[ed] a public image" (Hill Cole 1999: 10, as quoted in: Leahy 2005: 33). Royal entries into cities originated in the Middle Ages and continued until the ceremonious entry into London of James I for his coronation in 1604. Royal entries were the most public and theatrical signs of triumph and military victory, often in the form of thanks-giving. Due to their processional, ceremony-like character, they were organized to celebrate important events in the reign of the monarch, such as coronations, accessions, marriages, the birth of children, or deaths. In the middle of the $16^{\text {th }}$ century, such entries were enriched by shows/pageants displaying religious, moral and historical allegories, and the monarch's status was that of "the principal participant" in the event (Leahy 2005: 53). The procession of Elizabeth through the city of London on 14 January 1559, gathered thousands of citizens who watched her, addressed her, and performed for her; - the greatest 
performer, however, was the Queen herself. She was the most important actress in the play, dazzling the London city audience with her looks. According to Il Schifanoya, the Venetian ambassador who wrote a report on the procession to the Castellan of Mantua, Elizabeth was wearing "a royal robe of very rich cloth of gold", and a raised stiff pile, her hair was covered with "a coif of cloth of gold", while on her head a gold crown was set with precious stones, and on her hands nothing but gloves. The Queen's suite was composed of Dudley, Lord Chamberlain, and members of the Privy Council, equipped with a thousand horses (Il Schifanoya 1890: 12). As Leahy (2005: 65-67) notes, Mulcaster's report focuses on depicting there being a good rapport of the Queen with her subjects. She is shown as a monarch who is close to her people and reveals to them her personal side, for example, she is recorded to be consoling a crying man or laughing at the mention of her father. She is, nevertheless, an actress who at a procession skillfully "manipulates" the crowd, when, for instance, she sedates cheering citizens who disturb her in watching the shows.

In the royal entry speech is of secondary importance, what matters most is pageantry and drama (Bergeron 1971: 12). Elizabeth's pre-coronation entry was a spectacle, the city was completely reorganized for her sake - the citizens erected pageant stages on which shows were displayed. Pageants were set up at the conduits, little towers with water cisterns, which often had the look of a castle; scaffold stages, triumphal arches and other devices were constructed around, against and on top of conduits (Lees-Jeffries 2007: 66, 69). Elizabeth watched all five pageants in her procession through the city ${ }^{4}$, and though each show had a different theme (historical, allegorical/medieval, biblical) they were interconnected, as each pageant showed a metaphor of Elizabeth and offered the Queen words of instruction and warning in her kingship. In Gracious Street Elizabeth watched the figures of Henry VII and his queen Elizabeth on the lowest stage, and on the middle stage the actors representing her parents, Anne Boleyn and Henry VIII. On the top-most stage there was a royal seat for the Queen herself. Elizabeth's grandparents' red and white roses' branches were connected into one, which ascended to the highest stage, where the royal chair was situated. As for the symbolic meaning of the flowers, the pageant not only showed acceptance of Elizabeth as a legitimate Tudor heir, but also hinted at the need for a continuous unity in her kingdom (Bergeron 1971: 16-17). While at Cornhill, Elizabeth witnessed a show in the form of the medieval psychomachy, a battle between Vices and Virtues surrounding the erected chair of the monarch, "the seat of worthy governance" (Bergeron 1971: 17). A child

\footnotetext{
"Lancaster and York" pageant in Gracious Street, "Worthy Governance" at Cornhill, "Eight Beatitudes" on Soper's Lane, "The Two Commonwealths" pageant at the Little Conduit in Cheap, and "Deborah taking counsel" at the Conduit in Fleet Street (Lees-Jeffries 2007: 66).
} 
addressed the Queen to explain the meaning of this spectacle, and expressed the hope that only Virtues ("Pure religion", "Love of subjects", "Wisdom", "Justice") would accompany Elizabeth as Queen. Finally, in Fleet Street she saw a pageant composed of four towers with several levels, and on the highest level there was a chair and a palm tree behind it. It was a royal seat of the biblical Deborah, the great restorer of Israel and a "worthy judge". She had six advisers with her who represented the nobility, clergy and commonality. Deborah symbolized a wise counsel of advisers, which Elizabeth, as a good queen, should always heed (Bergeron 1971: 21-22). The common denominator of these shows is a chair raised high on a platform, a strong theatrical denotation of a royal throne, which serves as the metaphor of power, wisdom and virtue. In her speech to Parliament in 1586 Elizabeth compared kingship to theatre: "for we princes, I tell you, are set on stages in the sight and view of all the world duly observed" (Marcus et al. 2000: 194). How aptly then the fate of the Queen was equated with that of an actor, both put on display and both on a platform.

It is important to note that civic pageants required of the Queen that she not only be a mere spectator in the performance, but also that she take an active part in it. Elizabeth's visit to Wanstead in May, 1578, (or 1579) serves as a good example. At the manor house of the Earl of Leicester, near Greenwich, Sir Philip Sidney, Leicester's nephew, prepared a show in the form of a pastoral romance called "The lady of May". Elizabeth is seen strolling in the garden when suddenly she is stopped by an old woman and her daughter, who has been chosen "May Lady". The figures want the Queen to decide whom of the two suitors the young lady should choose: Espilus, a good and rich shepherd, or Therion, an entertaining forester, "both loving her, both equally liked of her, both striving to deserve / her" (The lady of May, 18-19). They turn to Elizabeth in a supplication:

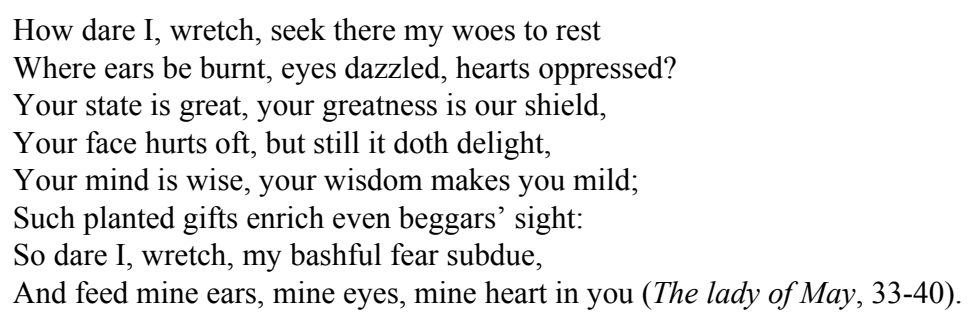

According to Bergeron (1971: 37), the figures do not fully recognize Elizabeth as queen, but they address her as the most noble and beautiful lady. Lalus, an old shepherd, undertakes to present the problem to the Queen and "give a little superfluous intelligence" (The lady of May, 53), but he is interrupted by Rombus the schoolmaster, who is showing off with his imperfect Latin speech. Sud- 
denly, from the wood emerge six shepherds, the supporters of Espilus, and a group of foresters, who cheer on Therion. The pageant relies heavily on words, both Espilus and Therion praise the virtues of the "May Lady" in a singing contest. They, too, approach Elizabeth and want her to decide on the perfect lover for the lady: "Judge you, to whom all beauty's force is lent" (The lady of May, 168) asks Espilus, kneeling to the Queen. The "May Lady" turns to Elizabeth for help and addresses her directly: "The / truth is, you excel me in that wherein I desire most to excel, and that / makes me give this homage unto you, as the beautifullest lady these / woods have ever received" (The lady of May, 109112). ${ }^{5}$ Hence, the Queen is made to react spontaneously and make a choice, and she is in this way involved in the drama and becomes an actress in the show prepared in her honour. Elizabeth chooses Espilus as a more suitable lover for "May Lady". When the music stops, the Queen wishes the company good night and, as a farewell gift, she receives a chain of agates from Rombus. Bergeron (1971: 36-37) claims that Therion in the pageant represents Leicester, that is Robert Dudley himself. In rejecting Therion Elizabeth gives her lack of preference for the Earl of Leicester as her lover; her theatrical choice in the drama is understood by the audience as her real choice as Queen. It can be observed that Elizabeth in civic pageants is the centre of attention, an active participant in the show. ${ }^{6}$ As Bergeron (1971: 64) rightly notes, even though no part was written specially for her, she is expected by the audience to react spontaneously, to mediate quarrels or receive gifts, and she functions as an "unscheduled actor" in the Renaissance civic pageant theatre.

A couple of years before, at a summer progress at Kenilworth in 1575, Elizabeth was asked to save a "Lady of the Lake" from death by a cruel knight. George Gascoigne in his Princely pleasures at the courte at Kenelwoorth $(1575)^{7}$ reports that at the beginning of the festivities Elizabeth witnessed a

5 The lady of May text is included in Helmingham Hall MS., Norfolk. Bergeron is using the transcript of the manuscript found in Robert Kimbrough and Philip Murphy "The Helmingham Hall Manuscript of Sidney's The lady of May: A Commentary and Transcription”, in: Renaissance Drama I, new series, edited by Samuel Schoenbaum (Evanston 1968), p. 109, 111.

6 Another example of a progress, during which the Queen is forced to turn into an actress is her visit to Bristol in 1574. Elizabeth was involved in a mock-battle between the allegorical War and Peace, which was organized by the citizens. She performed as a "judicial arbiter" deciding about who should win. The aim of this pageant was to persuade the Queen about the need for good foreign relations that would foster better trade, as the inhabitants were facing the decline of the Bristol harbour. The pageant lasted three days, and eventually the Queen decided that Peace will win. In this way she conveyed an important message to the Bristol citizens, namely that she would consider their request (Hill Cole 2007: 38).

7 Details of the Kenilworth entertainment are present in two contemporary printed accounts: A letter: Whearin, part of the entertainment, untoo the Queenz Maiesty, at Killingworth castl ... is signified (known as Langham's or Laneham's letter), and George Gascoigne's Princely pleasures at the courte at Kenelwoorth. 
spectacle showing the mythical "Lady of the Lake", the figure from the Arthurian legend, approaching her majesty on a movable island from the middle of the artificial lake. The Nymph greeted Elizabeth with a verse, introduced the story of the castle and assured the Queen that from now on she had the power over this lake (Gascoigne 1910: 9). Several days later Elizabeth was part of the pageant, in which Triton, swimming on a Mermaid, approached the Queen and with a sounding of the trumpet asked her to come onto the bridge. He told Elizabeth the story of the distressed Nymph from the lake, and asked Elizabeth to stay near the lake, explaining that "[her] only prezens shall be matter sufficient of abandoning this uncourtess knight, and putting all his bands too flight" (Laneham 1575: 41). The pageant shows the Queen in the role of a "deliverer"her mere presence is enough to protect from evil those who are close to her. Actually, in 1572 Elizabeth played a similar part in an entertainment at Sudeley castle, where she saved Daphne from Apollo (Woodcock 2003: 111). The Sudeley show, like many others, alluded to her reluctance to marry. Thus, Elizabeth's saving Daphne was a symbolic act which mirrored the Queen's personal life, as she "saved" herself from an undesirable state of matrimony. To follow Montrose (1980: 170), it can be said that on progresses Elizabeth participated in a play-within-the-play, she played the most significant part in the "social drama". To be sure, in Sudeley and Kenilworth Elizabeth played herself.

The Queen attended twenty three progresses during her forty-four-year reign. The tradition of visiting the households of noblemen around England she took over from her ancestors: Henry VII established royal progresses with his military triumphs in northern England in 1486 and 1487. The aim of a progress was to display the "personal nature of sovereignty", to show a private face of the king. It was an opportunity for the whole country to see, meet and entertain the monarch (Hill Cole 2007: 27-28). A significant element of Elizabethan royal progresses was the "ceremonial dialogue" between the Queen and her subjects, which consisted in "parades, welcomes, orations, and gifts exchanged" between Elizabeth and her civic hosts. The aura of ceremony was enhanced by the rich imagery of visual display (shows, pageants), theatrical gestures and clothing. Her most well known progresses were her travels to Coventry, Warwick, Kenilworth and Worcester in the 1560s and 1570s (Hill Cole 1996: 84-85). Elizabeth usually visited those who supported her sovereignty, her visits extended from several days to a couple of weeks. ${ }^{8}$ Progresses were a great opportunity for

The 1575 progress at Kenilworth lasted 19 days, from 9 to 27 July, but many other visits to the countryside extended even to one month. Even though Elizabeth usually visited very rich noble households, it was always with "an enormous retinue" (progresses were a means to live and maintain the court). Her plan for popularity was, actually, very costly for her hosts, who would find themselves bankrupt after the Queen's departure (Greenblatt 2004: 42-43). 
the Queen to display herself and to "fashion" a favourable image of her kingship with common people. Heal (2007: 52) states that during progresses the monarch emerged as visible and accessible from normal courtly life. The contact of the Queen with the citizens strengthened their mutual bond, the Queen was seen strolling the streets of their towns and villages like a common person, she talked with peasants. However, Frye (1993: 82) notes that Elizabethan progresses were never free from politics, as this seeming closeness to the people was actually her idea of fostering loyalty, and each procession was her "plan for popularity".

To conclude, the kingship of Elizabeth I is a successful display of acting skills. To follow Elam (1980: 22-23), theatrical iconicity is based on the absolute (or very apparent) visual similarity between sign and its object. When an actor on stage shows/plays himself, the sign becomes the object. Similarly, Elizabeth constructs a perfect icon in the Renaissance, she is a Queen who plays the Queen. During her progresses she physically displays the theatricality of her figure; in her speeches to parliament she poses as important cultural and religious icons: the mother of the nation or the Virgin Mary. Her theatrical behaviour is to support her difficult reign - she has a status of a royal bastard, she is a woman ruling in the world of men and of factionalism in politics, thus, displaying and manipulating her public image is the best way to raise her prestige as a monarch. Kastan (1986: 467) claims that the Elizabethan audience in playhouses did not keep "a respectful distance" towards the stage (literal, physical distance) and towards characters on the stage (they were freely judged and criticized). When a king (theatrical figure) appeared on stage, he would also be judged by the spectators - he would become "a subject", his "majesty" was belittled, as "representation ... undermines rather than confirms authority, denying it its presumptive dignity by subjecting it to common view" (Kastan 1986: 462). This, however, rarely happens in the real life. Elizabeth's state spectacles, her entries and progresses with all their ceremony and ritual, were to intimidate the subjects, to make them feel awe before the royal person rather than foster mutual relations. The Queen practised what Greenblatt (1985: 297) calls "privileged visibility" - the Elizabethan people as audience in the theatre were "visibly engaged" in her presence on the one hand, but they had to keep at a distance from the greatness and majesty displayed before them. 


\section{REFERENCES}

\section{PRIMARY SOURCES}

Arber, Edward (ed.)

[1588]

2006 The first blast of the trumpet against the monstrous regiment of women. Teddington, UK: The Echo Library.

Ellis, Henry (ed.)

1807-1808 Holinshed's Chronicles. Vol. 4. London: J. Johnson.

Gascoigne, George

[1574]

1910 The complete works of George Gascoigne. Vol. 2. (Edited by John W. Cunliffe.) Cambridge: [no indication of publisher].

James I

[1598]

2003 Basilicon Doron, in: Neil Rhodes, et al. (eds.), 199-258.

Il Schifanoya

[1558]

1890 Calendar of state papers Venetian 1558-1580. Vol. 7. London: [no indication of publisher].

Laneham, Robert

1575 A letter: Whearin, part of the entertainment untoo the Queenz Majesty, at Killingworth castl... is signified. London: [no indication of publisher].

Marcus, Leah S. - Janel Mueller - Mary B. Rose (eds.)

2000 Elizabeth I. Collected works. Chicago - London: University of Chicago Press.

Mulcaster, Richard

[1558]

1559 The passage of our most dread soveraige lady queen Elyzabeth through the citie of London to Westminster the daye before her coronation. London: [no indication of publisher].

Rhodes, Neil - Jennifer Richards - Joseph Marshall (eds.)

2003 King James VI and I. Selected writings. Aldershot - Burlington: Ashgate.

Sidney, Philip

2008 Sir Philip Sidney: the major works. The lady of May (Edited by Katherine DuncanJones.) Oxford - New York: Oxford University Press.

\section{SECONDARY SOURCES}

Archer, Jean E. - Elizabeth Goldring - Sarah Knight (eds.)

2007 The progresses, pageants, and entertainments of Queen Elizabeth I. Oxford: Oxford University Press.

Bergeron, David M

1971 English civic pageantry 1558-1642. London: Edward Arnold.

Bindoff, S. T. 
1950 Tudor England. Harmondsworth: Penguin Books.

Black, James

1959 The reign of Elizabeth 1558-1603. (2nd edition.) Oxford: The Clarendon Press.

Cerasano, S. P. - Marion Wynne-Davies

1992 "From myself, my other self I turned: An introduction", in: S. P. Cerasano - MarionWynne-Davies (eds.), 1-24.

S. P. Cerasano, S. P. - MarionWynne-Davies (eds.)

1992 Gloriana's face. Women, public and private, in the English Renaissance. New YorkLondon - Toronto - Sydney: Harvester Wheatsheaf.

Elam, Keir

1980 The semiotics of theatre and drama. London - New York: Methuen.

Erickson, Peter - Coppélia Kahn (eds.)

1985 Shakespeare's rough magic. Renaissance essays in honour of C. L. Barber. Newark: University of Delaware Press.

Frye, Susan

1993 Elizabeth I. The competition for representation. New York - Oxford: Oxford University Press.

Greenblatt, Stephen

1985 "Invisible bullets: Renaissance authority and its subversion", in: Peter Erickson Coppélia Kahn (eds.), 276-301.

2004 Will in the world. How Shakespeare became Shakespeare. London: Jonathan Cape.

Heal, Felicity

2007 "Giving and receiving on royal progresses", in: Jane E. Archer, et al. (eds.), 46-61.

Hill Cole, Mary

1996 "Ceremonial dialogue between Elizabeth I and her civic hosts", in: Douglas F. Routledge (ed.), 84-100.

1999 The portable queen: Elizabeth I and the politics of civil ceremony. Amherst: University of Massachusetts Press.

2007 "Monarchy in motion: An overview of Elizabethan progresses", in: Jane E. Archer, et al. (eds.), 27-45.

Kamps, Ivo (ed.)

1991 Shakespeare left and right. New York - London: Routledge.

Kastan, David Scott

1986 "Proud majesty made a subject: Shakespeare and the spectacle of rule", Shakespeare Quarterly 37: 459-475.

1991 “"The king hath many marching in his coats', or, what did you do in the war, daddy?", in: Ivo Kamps (ed.), 241-258.

Leahy, William

2005 Elizabethan triumphal processions. Aldershot - Burlington: Ashgate.

Lees-Jeffries, Hester

2007 "Location as metaphor in Queen Elizabeth's coronation entry (1559): Veritas Temporis Filia", in: Jane E. Archer, et al. (eds.), 65-85.

Levin, Carole

1994 The heart and stomach of a king. Elizabeth I and the politics of sex and power. Philadelphia: University of Pennsylvania Press.

Levin, Carole - Jo Eldridge Carney - Debra Barret-Graves (eds.)

2003 Elizabeth I. Always her own free woman. Aldershot - Burlington: Ashgate. 
Montini, Donatella

1999 "The regal illusion: Machiavellian strategies in the speeches of Elizabeth I and in Shakespeare's Henry V', Shakespeare Yearbook 10: 211-224.

Montrose, Louis A.

1980 “"Eliza, Queen of shepheardes' and the pastoral of power", English Literary Renaissance 10/2: 153-182.

Mueller, Janel

2000 “"To my very good brother the King of Scots': Elizabeth I's correspondence with James VI and the question of the succession", PMLA 115: 1063-1071.

Rose, Mary B.

2002 Gender and heroism in Early Modern English literature. Chicago - London: The University of Chicago Press.

Routledge, Douglas F. (ed.)

1996 Ceremony and text in the Renaissance. Delaware - Newark: University of Delaware Press.

Woodcock, Matthew

2003 "The Fairy Queen figure in Elizabethan entertainments", in: Carole Levin et al. (eds.), $97-115$. 